\title{
The Atlanta Public Schools Scandal: Educator Fraud, RICO, And COSO
}

Dr. Jan Colbert, Columbus State University, USA

\begin{abstract}
As the new Chief Audit Executive (CAE) of the school district in Big City, you are interested in the lessons regarding internal control which can be learned from educator fraud (cheating) which occurred in the Atlanta Public Schools (APS) scandal. You discover that educators erased students' wrong answers and changed them to right answers, that educators made false certifications of test results, and that tests were opened (and resealed) prior to administration. The cheating went on for years. Multiple investigations ensued and the Georgia Bureau of Investigation eventually became involved. About 150 educators resigned, retired or lost their appeals to have their jobs reinstated. Educators who chose to go to trial were prosecuted under the RICO statute (Racketeer Influenced and Corrupt Organizations Act). The APS eventually begun making remediation efforts for the students impacted by false test results. To attempt to prevent such cheating and fraud from occurring again, you relate the facts of the case to both the COSO internal control framework and to the fraud triangle. As CAE, you will use this information to instruct the internal auditors in your department.
\end{abstract}

Keywords: Educator Fraud; RICO; COSO; Atlanta Public Schools, Cheating; Internal Control

\section{LEARNING OBJECTIVES}

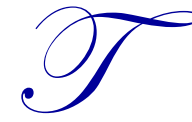

his case is intended to be used in Masters level courses such as MBA courses and Masters in Accountancy courses as well as in Masters in Public Administration courses. Also, the case is appropriate for upper level undergraduate courses such as Auditing and Assurance Services, Enterprise Risk Management, and Internal Control.

1. The first objective is to show, through a real-life example, how RICO (Racketeer Influenced and Corrupt Organizations Act) was utilized to prosecute educators who cheated.

2. The second objective is to illustrate how having the principles and components of the COSO (Committee of Sponsoring Organization of the Treadway Commission) framework in place could have helped prevent this fraud which impacted the learning of a generation of students.

3. The fourth objective is to consider the three points of the fraud triangle and whether they were present in the Atlanta Public Schools (APS) case.

4. The third objective is to show, through a situation which actually occurred, how far-reaching and longlasting a fraud can be and how it can impact so many people.

\section{CASE SYNOPSIS}

You are the new Chief Audit Executive (CAE) of the school district in Big City. You have heard of the cheating scandal in the Atlanta Public Schools (APS) and want to learn from it. Your review of the APS scandal reveals that Dr. Beverly Hall was hired as Superintendent of the Atlanta Public School (APS) system with an objective of bringing about change, specifically, an increase in standardized test scores. Within a few years, various schools within APS displayed remarkable improvement in test scores. A major newspaper investigated; this action was followed by an investigation by the state. The Atlanta school board was finally forced to form a Blue Ribbon Commission to study the matter. Cheating took the form of educators erasing students' wrong answers and inserting right answers, falsifying the certification of the results of tests, and opening the shrink-wrapped tests prior to administration and then resealing them. 
In the course of studying the APS cheating scandal, you consider the RICO statute, which was used to prosecute a number of the educators. Also, clearly, lack of internal control permitted the fraud (cheating) to occur and continue for a number of years; thus, you want to relate the APS situation to COSO's "Internal Control-Integrated Framework." Further, you recall the fraud triangle (opportunity, pressure, rationalization) from your auditing and fraud coursework and want to tie in the APS facts to those three points. Finally, you are interested in what, if anything, the APS did to remediate the situation for the students (and parents) impacted.

\section{RESEARCH METHODS}

This case is a synopsis of an actual case in which educators cheated and then conspired to cover their actions. The fraud took place over a period of years, in Atlanta, Georgia, USA. The information gathered is from journalistic accounts. The facts in the case are then related to the RICO statute, to the COSO internal control framework, and to the fraud triangle.

\section{CASE}

\section{Introduction}

You have recently been asked to serve as the Chief Audit Executive (CAE) of the internal audit department for a large urban school district in Big City, which is located in a Midwestern state of the USA. As part of preparing for the role and in anticipation of training the internal auditor professionals of the school district, you decide to review the Atlanta Public Schools (APS) cheating case. Your recollection is that prosecutors charged former educators under RICO, the Racketeer Influenced and Corrupt Organization Act; thus, that federal statute will be accessed and studied. Further, the control system in APS allowed the fraud to perpetuate for many years. To help ensure that the control system in the school district in Big City is adequate, you want to study the lack of controls in APS and relate any shortcomings to the COSO internal control framework. Finally, you recall learning about the concept of a fraud triangle when studying auditing and fraud; you want to go back and research the points of the fraud triangle and see how they relate to the APS case.

\section{Atlanta Public Schools-Cheating by Educators}

\section{The Atlanta Public Schools and its Superintendent}

In February of 2009, Dr. Beverly Hall, the Superintendent of the Atlanta Public Schools (APS), was honored to be named by the American Association of School Administrators (AASA), an organization of school superintendents, as National Superintendent of the Year. By 2013, the state of Georgia had investigated the APS and Dr. Hall. An Atlanta grand jury had indicted 35 of the educators in the APS for racketeering under the RICO statute in relation to cheating on state achievement tests. How could such a rapid and steep fall occur?

When Dr. Beverly Hall was appointed the $15^{\text {th }}$ superintendent of the APS system on July 1 , 1999, she set about undertaking aggressive reform. Her goal was to accelerate student achievement by utilizing nationally proven reform models. Dr. Hall came to Atlanta after an already successful career in New York and New Jersey. Rising from teacher to principal to superintendent in New York, she spent a year as deputy chancellor for instruction in the New York City Public schools. In 1995, New Jersey tapped her as the state district superintendent of its Newark public schools.

\section{Questionable Test Results}

Two years after Dr. Hall was appointed superintendent of the APS, one elementary school in the APS system already exhibited extraordinary results. Based on state achievement test scores, administered by the schools themselves, Dobbs Elementary, in a poor section of Atlanta, had been classified as a failing school in 2000 . By the next year, nearly all of its students passed the state achievement tests. In another school, Parks Middle School, 1\% of the students scored in the highest range on the CRCT (Criterion-Referenced Competency Test, Georgia's state achievement test) in 2006. Christopher Waller, the principal there, was credited with an amazing turnaround as one year later, $46 \%$ of the students at Parks scored in that same (highest) range. 
While these incredible results warranted a couple of newspaper articles, the matter largely died out. However, in late 2008, the Atlanta Journal Constitution (AJC) questioned scores on the CRCT in five elementary schools in the state of Georgia; one of the five was in Atlanta. The APS was not concerned and indicated that it did not plan to investigate the matter.

About two months later, in February of 2009, the American Association of School Administrators named Dr. Hall as its Superintendent of the Year. Despite the accolade, within a few months, state investigators found strong evidence of educator cheating at one APS school and three other schools in GA. A month later, the Georgia Board of Education threw out the math retest scores at these four schools. Despite the finding by the state investigators and the action of the GA Board of Education, Dr. Hall asserted that external investigators found no evidence of tampering by educators. Later in the summer of 2009, Dr. Hall boasted that APS was a model school district with double-digit test score gains. Yet, disturbingly, an AJC investigation found that APS did not follow up on allegations of test cheating.

By the fall of 2009, the AJC decided to statistically analyze the state test results. The newspaper's findings revealed that the increases in 12 APS schools' test results and seven others in GA were statistically all but impossible. Still, Dr. Hall maintained that cheating by educators did not occur. However, by November, Dr. Hall had finally succumbed to pressure; she announced that national experts were to review test scores that showed extraordinary improvements within APS.

\section{Investigations}

Early the next year, the Georgia Board of Education ordered that various schools across the state arrange for independent investigations of their test results. Of these, 58 were in APS. As a result of this mandate, the APS Board formed a Blue Ribbon Commission (BRC). The members of the BRC were chosen after considering recommendations from the APS Board, the Metro Atlanta Chamber, and the nonprofit Atlanta Education Fund, a district advocacy group. The members thus had business, social, or civic ties to Dr. Hall or to the APS. Meanwhile, the 2010 tests at APS were given under scrutiny. Test score results dropped districtwide and particularly at schools under investigation.

During the late spring and summer of 2010, the BRC performed its investigation. The BRC utilized Caveon Test Security, a company that specializes in forensic data analysis, to conduct analysis of erasures purportedly made by educators after students had completed the tests ('erasure analysis').

The BRC investigators interviewed about 300 people and reviewed about 50,000 emails. During the period of the investigation, the AJC reported that APS central office administrators took part in querying witnesses for the investigation, a practice the newspaper deemed questionable. School employees felt pressure from APS and expected retribution if they talked to investigators. For example, one regional superintendent, Tamara Cotman, told a group of principals to not cooperate with state investigators.

The Georgia Board of Education apparently felt the BRC investigation was dragging on too long, as the Board threatened to punish APS if the report on cheating was not submitted by August 2, 2010. The report was ultimately presented on that precise date. The BRC noted that cheating by educators occurred at 12 schools in APS. Still, the document downplayed irregularities in testing. Further, the report suppressed allegations that Dr. Hall knew about cheating within APS much earlier than she had acknowledged. While the APS Board at first refused the BRC findings, it relented and ended up accepting the report.

Following up on the BRC report, the AJC noted that the BRC investigators examined less than half of the 58 schools cited by the Georgia Board of Education. The Governor of Georgia (at that time), Sonny Perdue, believed that the $\mathrm{BRC}$ investigation was a sham. He went on to order a panel of special investigators to investigate possible educator cheating within APS. The trio of investigators, made up of a former police detective (Richard Hyde), a former attorney general (Mike Bowers), and a former county District attorney (Bob Wilson), was given subpoena power. At first, they found school employees hesitant to talk to them. Principals sometimes stationed themselves near the rooms where investigators were interviewing employees. The employees were clearly frightened. The investigators 
were challenged to find a way to break through the wall of silence and fear. Finally, a crack opened up via one of the investigator's connections.

Richard Hyde, the former police detective, had started his career as a police officer in the area around Venetian Hills Elementary, one of the schools under scrutiny. He went to work canvassing his old area and found one teacher from Venetian Hills who, wanting to unburden herself, agreed to talk. She was also willing to wear a wire. Armed with the evidence from the wire, the investigators went to the Georgia Bureau of Investigation (GBI). Agents from the GBI visited many of the schools being examined, interviewing personnel, parents, and students. They found a culture of fear of APS administrators and a conspiracy to stay silent about educator cheating. Evidence showed that top administrators in APS used intimidation to keep educators quiet about educator cheating. These factors worked together to perpetuate the cheating.

Shortly after the GBI began its investigation, Dr. Hall announced that she would retire from her Superintendent position. The effective date would be June of 2011.

As 2010 drew to a close, the District Attorney of Fulton County, in which Atlanta resides, appointed two special prosecutors to criminally look into APS. That action stemmed from concerns about educators lying to GBI agents and investigators as well as the destruction or altering of public documents. In relation to those charges, the AJC reported that Dr. Hall and other educators worked for more than two years to squash evidence regarding the cheating.

By early in 2011, the state investigators had found a pattern of intimidation, threats, and retaliation against APS educators who reported cheating. Because any work the APS was doing on its investigation would interfere with the state's investigation, the state investigators told APS to stop its investigation. However, APS refused. Only after a judge interceded and ordered APS to cease its investigation did APS halt.

The state investigation report, which ran over 800 pages, charged that cheating was pervasive and that Dr. Hall and other administrators benefited from it. The report noted "a culture of fear and a conspiracy of silence" that allowed the fraud to continue. Intimidation was used to keep educators from talking. There was no way to determine the number of students harmed by the cheating.

An independent group with a mission to accelerate student achievement in the Atlanta public schools, The Atlanta Education Fund, decided to contract with researchers to test the AJC findings. Andrew C. Porter and Jennifer McMaken of the University of Pennsylvania produced a report in which they examined the validity of the newspaper's findings. The Porter-McMaken study focused on students who were tested in the same school in both 2008 and 2009. The researchers asked for teacher-level data as well as item-level responses, but the state indicated it could not comply; the information furnished was at the grade level and only for grades 3, 4, and 5. The results of the Porter-McMaken study showed student achievement gains and losses that were highly unusual and which could be caused by cheating. Perhaps the most significant statement in the report was: “...it is also true that if a school cheated in 2008 to get better student achievement performance and then cheated again in 2009 in the same way, neither the newspaper analysis, nor our longitudinal and student demographic analysis would flag this school as an outlier with an unusually large residual."

In the summer of 2011, the AJC reported that a former educator, at a high level in the APS, stated that Dr. Hall had ordered the destruction of documents detailing cheating. Further, Dr. Hall had mandated that educators omit findings of cheating on various reports which detailed testing results. Meanwhile, the state investigation revealed a wide range of cheating violations, as well as systematic misconduct by educators in APS. A total of 178 educators from 44 elementary and middle schools were included in the report. Dr. Hall retired and Erroll Davis began his tenure as Interim School Superintendent.

\section{Educators Lose Their Jobs, Prosecution of Educators}

In early 2012, the APS finally appeared to take the cheating seriously. The month of February saw the educators implicated in the state investigation report being given one day to resign or face firing. The next month, the district began disciplinary tribunals for those appealing their dismissals. These educators also were facing the loss or 
suspension of their teaching licenses. The body in Georgia which handles teaching licenses, the Georgia Professional Standards Commission (PSC), made a decision to not hear appeals in the cases against the educators until the criminal investigation was completed.

By the summer of 2012, APS decided that there was not enough evidence to dismiss 12 of the educators who had been named in the state investigation report; those 12 were allowed to return to their APS duties. A month after this decision was made, a principal who had been accused in the case was reinstated to a position, albeit a different job, as it was deemed that there was insufficient evidence to prove she had violated testing protocol.

Near the end of 2012, the APS Board chose to extend Erroll Davis' contract. The Interim Superintendent's contract had been set to expire in June, 2013; it was continued for another 18 months. (Superintendent Davis had stated that he did not want the position for the long-term.)

By the beginning of 2013, out of the 178 educators originally named in the state investigation report, 21 were reinstated and three were awaiting their appeals. Just over 150 had resigned, retired, or lost their appeals.

Later in 2013, one former educator, Tamara Cotman, who had overseen 21 schools, was found not guilty of trying to influence a witness. However, she still faced charges of racketeering. A month later, Lisa Terry, a former teacher, chose to apologize for her actions. In exchange for pleading guilty to a misdemeanor charge of obstruction, she agreed to testify for the prosecution. A principal in APS, Armstead Salters, plead guilty to one felony count of making false statements and writing at the very end of 2013. Prosecutors believed that in his school, cheating had occurred for years.

A human resources (HR) director, Millicent Few, followed Mr. Salters' lead early the next year. She plead guilty to misdemeanor malfeasance in office. The expectation was that she would testify that Dr. Hall ordered the destruction of internal investigative reports detailing cheating in APS. That same month, February, 2014, 21 educators plead guilty. Of the 35 indicted, 14 were left to stand trial. One died while awaiting trial. Attorneys for Dr. Hall argued that she was too ill to stand trial, as she had Stage IV breast cancer.

In April of 2014, it was revealed that Dr. Hall had tried to work out an agreement with prosecutors in which she would plead guilty to a single felony charge in exchange for probation. However, that deal fell through when she refused to admit to any wrongdoing.

\section{Trial}

By the time the trial commenced, Christopher Waller, the former principal at Parks Middle School which had supposedly achieved an increase in scores in the highest CRCT range from $1 \%$ of its students to $46 \%$ in one year, had plead guilty to making false statements. He received probation and was ordered to pay $\$ 50,000$.

The judge in the case, Jerry Baxter, set the trial to begin in August, 2014; it actually started in September. The trial covered 12 defendants and did not include Dr. Hall. The case continued through the remainder of 2014 and into 2015.

Dr. Hall passed away from breast cancer in March of 2015, about two weeks before closing arguments. The case, brought under the RICO statute, went to the jury on March 19. On April 1, the jury returned guilty verdicts of racketeering and other felony charges for 11 of the 12 defendants. Further, it was determined that eight of the educators had participated in a "criminal enterprise."

When the judge handed down the sentences, he was quite tough. Clearly, he was frustrated that the defendants had not admitted their guilt. Three of the former educators, all having served as school reform team executive directors, received seven years in prison, 13 years on probation, and $\$ 25,000$ in fines. After backlash from the community, the prison time was reduced to three years, probation went down to seven years, the fines were reduced to $\$ 10,000$, and community service (2,000 hours) was added. Sentences given to other educators were not altered. (All of the defendants appealed and were released on bond.) 
Table 1 presents a timeline of the events in the APS scandal while Table 2 summarizes the convictions, pleas, and other results for the accused.

Table 1. Timeline - Atlanta Public Schools Cheating Scandal

\begin{tabular}{|c|c|}
\hline 1999, Jul. 1 & Dr. Beverly Hall hired as Atlanta Public Schools (APS) Superintendent \\
\hline 2001 & $\begin{array}{l}\text { Dobbs Elementary School, an APS school, moved from being a 'failing' school the previous school year to } \\
\text { having almost all of its students pass state achievement tests. }\end{array}$ \\
\hline 2008, Dec. & $\begin{array}{l}\text { AJC investigation reports questionable scores on CRCT in five elementary schools, including one in Atlanta. } \\
\text { The APS indicates that it has no plans to investigate. }\end{array}$ \\
\hline 2009, Feb. & Dr. Hall is named Superintendent of the Year by the American Association of School Administrators (AASA). \\
\hline 2009, Jun. & $\begin{array}{l}\text { State investigation find strong evidence of educator cheating on retests at one APS school and three in other } \\
\text { school districts in GA. }\end{array}$ \\
\hline 2009, Jul. & $\begin{array}{l}\text { The GA Board of Education throws out math retest scores from Deerwood Academy, an Atlanta public school, } \\
\text { as well as three other schools. Superintendent Hall states that external investigators found no evidence of } \\
\text { tampering. }\end{array}$ \\
\hline 2009, Aug. & $\begin{array}{l}\text { Dr. Hall boasts that APS is a model urban school district and has high (double-digit) test score gains. The } \\
\text { Atlanta Journal Constitution (AJC) investigates and finds that the APS does not follow-up on allegations of test } \\
\text { cheating. }\end{array}$ \\
\hline 2009, Oct. & $\begin{array}{l}\text { The AJC statistically analyzes state test results. The analysis reveals statistically improbable score increases at } \\
12 \text { APS schools and seven others in GA. Dr. Hall states that she does not believe that cheating occurred. }\end{array}$ \\
\hline 2009, Nov. & $\begin{array}{l}\text { Dr. Hall announces that national experts will review test scores at schools in APS which showed extraordinary } \\
\text { improvements. }\end{array}$ \\
\hline 2010, Feb. & $\begin{array}{l}\text { The GA Board of Education orders various school districts to investigate } 191 \text { schools across the state. These } \\
\text { include } 58 \text { in APS. }\end{array}$ \\
\hline 2010, Mar. & $\begin{array}{l}\text { The Atlanta school board announces that a Blue Ribbon Commission (BRC) has been formed to oversee the } \\
\text { investigation of possible cheating. Members are to be chosen from recommendations from the board, the Metro } \\
\text { Atlanta Chamber, and the nonprofit Atlanta Education Fund, a district advocacy group. }\end{array}$ \\
\hline 2010, May 11 & $\begin{array}{l}\text { Andrew C. Porter and Jennifer McMaken of the University of Pennsylvania issue their report, requested by The } \\
\text { Atlanta Education Fund, investigating the validity of the AJC findings on CRCT results. The pair notes that the } \\
\text { highly unusual CRCT results could be caused by cheating and that if a school cheated in } 2008 \text { and again in } \\
2009 \text { in the same manner, the study would not be able to locate the cheating. }\end{array}$ \\
\hline 2010. Jul. & $\begin{array}{l}\text { The state board of education threatens to punish APS if it does not submit a report on the cheating investigation } \\
\text { by Aug. 2. Also, the AJC reports that the BRC members had ties to Dr. Hall or to the APS and further, that } \\
\text { central office administrators took part in querying witnesses for the BRC investigation. }\end{array}$ \\
\hline 2010, Aug. & $\begin{array}{l}\text { The APS board initially refused to accept the BRC finding of cheating, but later relents and accepted the results. } \\
\text { The BRC finds that cheating occurred in } 12 \text { schools. The AJC reports that the investigators examined less than } \\
\text { half of the } 58 \text { schools which displayed questionable results. Gov. Sonny Perdue announces that special } \\
\text { investigators will examine the APS cheating scandal. }\end{array}$ \\
\hline 2010, Oct. & Georgia Bureau of Investigation (GBI) agents begin interviews with APS educators about cheating. \\
\hline 2010, Nov. & Dr. Hall announces she will retire in June, 2011. \\
\hline 2010, Dec. & $\begin{array}{l}\text { Fulton County District Attorney Paul Howard appoints two special prosecutors to criminally probe APS. The } \\
\text { allegations encompass lying to GBI agents and investigators and the destruction or altering of public } \\
\text { documents. The AJC reports that Dr. Hall and others worked for over two years to squash evidence regarding } \\
\text { the cheating. }\end{array}$ \\
\hline 2011, Feb. & $\begin{array}{l}\text { State investigators find a pattern of intimidation, threats, and retaliation against APS educators who report } \\
\text { cheating. The state investigators tell APS to stop work on its own cheating investigation, as it would interfere } \\
\text { with the state's investigation. The APS refuses. A judge orders the APS to stop its own investigation; the state } \\
\text { proceeds with its investigation. }\end{array}$ \\
\hline 2011, May & $\begin{array}{l}\text { Dr. Hall presents recommendations covering four areas regarding the CRCT to the APS Board: security, } \\
\text { process, leadership, comparison. These recommendations are from the BRC report. }\end{array}$ \\
\hline 2011, Jul. & $\begin{array}{l}\text { The AJC reports that a former high level educator in APS stated that Dr. Hall ordered the destruction } \\
\text { of documents detailing cheating and ordered educators to omit findings of cheating. }\end{array}$ \\
\hline 2011, Jul. & $\begin{array}{l}\text { State investigators note a wide range of cheating violations, as well as systemic misconduct in APS. } \\
\text { The names of } 178 \text { educators in } 44 \text { schools are reported. }\end{array}$ \\
\hline 2011, Jul. & Dr. Hall retires at the end of July. Interim School Superintendent Erroll Davis takes over. \\
\hline 2012, Feb. & report that they have one day to resign or face firing. \\
\hline
\end{tabular}

(Table 1 continued on next page) 
(Table 1 continued)

\begin{tabular}{|c|c|}
\hline 2012, Mar. & $\begin{array}{l}\text { APS begins disciplinary tribunals for educators accused of cheating who are appealing their dismissals. The } \\
\text { educators also face suspension or revocation of their teaching licenses by the Georgia Professional Standards } \\
\text { Commission (PSC). The PSC decides not to hear appeals in the cases until the criminal investigation is } \\
\text { complete. }\end{array}$ \\
\hline 2012, Jun. & $\begin{array}{l}\text { APS permits } 12 \text { educators who had been named in the investigation to return to the classroom; there was not } \\
\text { enough evidence to dismiss them. }\end{array}$ \\
\hline 2012, Jul. & $\begin{array}{l}\text { One principal, who had been accused in the cheating scandal, was reinstated into an APS job at central office; } \\
\text { there was insufficient evidence to prove she had violated testing protocol. }\end{array}$ \\
\hline 2012, Dec. & $\begin{array}{l}\text { The contract of Superintendent Erroll Davis, who accepted the job on an interim basis, is extended } \\
18 \text { months beyond its expiration in June, 2013. Superintendent Davis has indicated he does not want the } \\
\text { position long-term. }\end{array}$ \\
\hline 2013, Mar. & $\begin{array}{l}\text { By this point, out of the } 178 \text { educators originally implicated in the state report, } 21 \text { were reinstated and three are } \\
\text { awaiting appeals. About } 150 \text { resigned, retired, or lost their appeals. }\end{array}$ \\
\hline 2013, Apr. & $\begin{array}{l}\text { Dr. Hall and } 34 \text { others met a deadline to turn themselves in at the Fulton County jail. Dr. Hall's bond was } \\
\$ 200,000 \text {. }\end{array}$ \\
\hline 2013, Sept. & $\begin{array}{l}\text { Tamara Cotman is found not guilty of trying to influence a witness. She still faces charges of racketeering. } \\
\text { Cotman had overseen } 21 \text { APS schools. }\end{array}$ \\
\hline 2013, Oct. & $\begin{array}{l}\text { Lisa Terry, a former teacher, apologizes for her actions. She pleads guilty to a misdemeanor charge of } \\
\text { obstruction and agrees to testify for the prosecution. }\end{array}$ \\
\hline 2013, Dec. & $\begin{array}{l}\text { Armstead Salters, a principal in the APS, pleads guilty to one felony count of making false statements and } \\
\text { writings. Prosecutors believed that cheating had been going on at Salters' school for years. }\end{array}$ \\
\hline 2014, Feb. & $\begin{array}{l}\text { Millicent Few pleads guilty to misdemeanor malfeasance in office. Few is a former human resources (HR) } \\
\text { director for APS. It is expected that Few will testify that Dr. Hall ordered the destruction of internal } \\
\text { investigative reports regarding cheating in APS. }\end{array}$ \\
\hline 2014, Feb. & $\begin{array}{l}\text { Out of } 35 \text { educators indicted, } 21 \text { plead guilty. One defendant dies while awaiting trial and } 13 \text { are left to stand } \\
\text { trial. The attorneys for Dr. Hall state that she has Stage IV breast cancer and is too ill to stand trial. }\end{array}$ \\
\hline 2014, Apr. & $\begin{array}{l}\text { Revelations come out that Dr. Hall had tried to work out an agreement in which she would plead guilty to a } \\
\text { single felony charge in exchange for probation. The deal fell through when she would not admit to } \\
\text { wrongdoing. }\end{array}$ \\
\hline 2014, Apr. & A hearing is held on whether Dr. Hall can withstand a trial. \\
\hline 2014, Jul. & $\begin{array}{l}\text { The judge in the case, Jerry Baxter, sets the trial for August, } 2014 \text { for } 12 \text { defendants. Dr. Hall is not included in } \\
\text { the } 12 .\end{array}$ \\
\hline 2014, Sep. & Trial begins in Fulton County. \\
\hline 2015, Mar. 02 & Dr. Hall dies of breast cancer at age 68 . \\
\hline 2015, Mar. 16 & Closing statements are given in the trial. \\
\hline 2015, Mar. 19 & The cheating case goes to the jury. \\
\hline 2015, Apr. 1 & $\begin{array}{l}\text { Guilty verdicts for racketeering and other felonies brought under the RICO statute for } 11 \text { of the } 12 \text { defendants } \\
\text { are returned. }\end{array}$ \\
\hline 2015, Apr. 30 & $\begin{array}{l}\text { Judge reduces the original sentences set for three of the defendants from seven years in prison to three years in } \\
\text { prison and other punishment. }\end{array}$ \\
\hline
\end{tabular}

Table 2. Summary of Convictions, Guilty Pleas, Other Results for the Accused

\begin{tabular}{l|l}
\hline District administrators (superintendents, area superintendents, HR Director) & three convictions, one plead guilty, one died. \\
\hline Principals, Assistant Principals & two convictions, five plead guilty, one died. \\
\hline Testing Coordinators, Instructional Coaches & two convictions, five plead guilty. \\
\hline Teachers & four convictions, nine plead guilty, one acquittal. \\
\hline Support Staff & one plead guilty. \\
\hline About 150 educators & resigned, retired, or lost their appeals. \\
\hline
\end{tabular}

\section{How did the Educators Cheat? How Long did the Cheating Go On?}

As CAE, you are responsible to provide assurance not only on financial information for the school district of Big City, but also on compliance with laws and regulations. Thus, you are interested in clearly identifying the ways in which educators at APS cheated and how long the cheating purportedly went on. 
The cheating in APS took various forms. For example, one teacher sliced open shrink-wrapped package of tests, made photocopies of the actual tests, and then used a lighter to reseal the plastic.

Another manner in which cheating took place was to alter the answer sheets for the tests. Sometimes these alterations took place during the school day, when employees papered over office windows to avoid detection. One school threw an after school party "cheating party" to allow educators time to alter answer sheets by erasure, while they imbibed. In addition, some answer sheets were completely fabricated.

Part of the achievement test process in APS was for administrators to certify the process and the results. False certifications by administrators were another form of educator cheating.

The prosecutors believed that the cheating dated from 2001; that is when scores on state aptitude tests improved greatly. The indictment filed by the prosecutors also stated that for at least four years, between 2005 and 2009, test answers were fabricated, altered, or falsely certified.

\section{FRAUD TRIANGLE}

During your auditing and fraud classes in college, you remember learning about the fraud triangle. This concept notes that if the three "points" of the fraud triangle are present, it is more likely that fraud (cheating) will occur. The three points are: opportunity, pressure (or incentive), rationalization. As CAE of the school district for Big City, you decide to consider if and how much each of the three points were present in the APS case. First, you learn a bit more about the culture of the organization (APS).

\section{Culture of the Organization}

Dr. Hall's motto was: "No exceptions, no excuses." That attitude permeated the culture of the organization.

The 1999 contract under which Dr. Hall was hired included a large financial incentive. She would receive up to $30 \%$ of her annual salary for meeting certain performance objectives. These objectives included test scores and attendance.

To incentivize the APS educators, Dr. Hall had set annual performance objectives or "targets" for elementary and middle schools. These were mostly based on the results of the CRCT. If a school met at least $70 \%$ of the targets, all employees in the school received a bonus. APS employees who failed to meet targets were either threatened with termination or were terminated.

Besides these financial incentives, Dr. Hall used a form of shaming to spur the educators on. At an annual APS convocation held at the Georgia Dome (a large convention center in downtown Atlanta), educators representing schools that had met the targets for the test scores were permitted to sit near the arena's stage. The remaining educators were forced to occupy seats on the bleachers.

\section{Three Points of the Fraud Triangle}

With the culture of the APS organization in mind, you turn to the fraud triangle. Again, the three points are: opportunity, pressure (incentive), and rationalization. If all three factors are present in a situation, it is theorized that fraud (cheating) is more likely to occur. You examine the presence of each factor in the APS case in turn.

The opportunity to commit fraud (i.e., cheating) was present in the APS. One teacher was able to slice open shrinkwrapped tests, make copies of them and then reseal the plastic, apparently without detection. Thus, adequate internal controls were not in place over access to the tests. Also, educators, who colluded in groups, were readily able to erase and change answers on tests which students had taken. Further, false certifications of test results were made by administrators. Thus, the cheating occurred by various forms and over a number of years. The culture of the organization contributed to the promotion of the cheating. 
Dr. Hall's contract, which included the bonus of up to $30 \%$ of her annual salary for meeting certain performance objectives (based on test scores and attendance), incentivized her to engage in the actions she did. By the time she retired, she had collected more than $\$ 580,000$ in bonuses from APS. For others, the monetary incentive may not have been as large as Dr. Hall's quantitatively, but was at least as important. School employees were afraid of losing their jobs if they did not go along with the cheating.

People who cheat or commit fraud normally have a way to rationalize their actions, even to themselves. Many of the educators who cheated were single parents who relied on their school salaries to support their families. They must have felt cheating was their only choice when superiors demanded higher test scores; they were afraid of losing their jobs if they did not go along with the schemes. One teacher used cynicism, saying her students were too dumb to learn.

Mike Bowers, one of the special investigators (the former GA attorney general) appointed by former Governor Perdue, said that educators cheated out of pride, to earn bonuses, and to enhance their careers or keep their jobs. The AJC noted that educators weren't so much trying to earn more money as attempting to keep their careers from running off track.

\section{RICO}

You noticed, in reading the APS case, reference to RICO (Racketeer Influenced and Corrupt Organization Act). As a CAE of the school district in Big City, you feel this is a statute that you should be familiar with, particularly as it related to the APS case.

From the FBI website, you note that organized crime, which is prosecuted under RICO, is crime committed through some manner of formalized structure. The primary objective of organized crime is to obtain money through illegal activities. One way in which groups involved in organized crime maintain their position is through corrupt public officials.

The APS case fits these descriptions. Dr. Hall and other educators (public officials) were actively involved in the cheating. Not only was the cheating illegal, but also, filing false test score reports, destroying documents, and making false statements to the GBI, was against the law. Thus, the defendants were prosecuted under RICO.

\section{COSO}

As a CAE, you are very familiar with COSO's (Committee of Sponsoring Organizations of the Treadway Commission) "Internal Control-Integrated Framework" (2013). The document notes that internal control includes five components and 17 principles. You believe that reviewing COSO and relating the five components and 17 principles to the APS case may be useful in ascertaining what areas of internal control could have been improved in the APS system. You find that three of the components and some of the principles related to those components are particularly pertinent to the APS case.

\section{Control Environment}

The first component in COSO is the control environment. COSO notes that senior management and the board establish the tone at the top regarding the importance of internal control. The first principle, which is related to the control environment, is the organization demonstrates a commitment to integrity and ethical values.

Dr. Hall helped set the tone at the top (or the culture or the organization) quickly with her motto of, "no exceptions, no excuses." Further, the Board had incentivized her by the contract (with the bonus offer) that it had given her. Even when evidence of educator cheating was brought to light, the Board did not act quickly and decisively to investigate and deal with the situation. 


\section{Risk Assessment}

COSO notes that risk is the possibility that an event will occur and adversely affect the achievement of objectives. Two principles related to risk assessment are particularly pertinent to the APS case. Principle 7 notes that risks should be managed and principle 8 states that an organization should consider the potential for fraud in assessing risks in the organization.

In hindsight, it is easy to see that educator cheating could occur and the ways in which cheating could be accomplished. However, even when cheating was brought to light, the Board did not act and the cheating continued. Thus, the risks were not managed.

\section{Monitoring}

The fifth component of internal control is monitoring. Ongoing evaluations, separate evaluations, or a combination of both are used to determine if the components of internal control, including the principles within the components, are present in the organization and if they are functioning. Principle 16 states that an organization performs ongoing and/or separate evaluations while principle 17 notes that internal control deficiencies (i.e., found during the evaluations) should be communicated to those who are able to take corrective action (the Board).

It is not clear if there was an internal audit function within the APS. However, investigations by other bodies (the AJC, the state) did occur. Once those investigations began, the Board initially refused to take action. Only when the APS case made its way to the courts did the Board act.

\section{WHAT ABOUT THE STUDENTS?}

As CAE, you are acutely aware that you report to the Board. In turn, the Board ultimately works for the students (and the parents). Thus, while it is critical to study the APS scandal in terms of fraud, RICO, and internal control, focusing on the students and the impact of the cheating on them is also important. Can the situation be made right for them?

Parents and students used students' test scores to gauge student progress; with falsified scores, the parents and students have no way of knowing what the actual progress was. In fact, during the course of the cheating scandal, some parents questioned their child's unexpected (high) performance, which was apparently the result of educators' cheating. In one case, a child was diagnosed with a learning disability and sought help from the schools. However, her (inflated) test score prevented her from getting that help.

The 2015 APS "CRCT Erasure Analysis and Ongoing Remediation Update" notes that the cheating disproportionately impacted black students. Another 2015 work, APS' "The Long-Run Effects of Teacher Cheating on Student Outcomes," finds that teachers were selective in their manipulation of test scores; there is strong evidence that teachers were more likely to change answers for students of apparently lower ability.

The impact on the students of the APS cheating is, of course, of the gravest concern. Alan Judd, in The Atlanta Journal Constitution, stated, "The miseducation of thousands of Atlanta students, especially the poorest among them, deprived an entire generation of an honest assessment of their academic abilities. It is doubtful they can ever be made whole" (04.04.2015). The state investigators went on to note that an unknowable number of students suffered the consequences of the cheating.

The APS eventually acknowledged the educator cheating and both initiated interventions to aid students who may have been impacted and altered the way in which standardized tests were administered. A twelve week accelerated academic recovery program for students who scored below proficient on the Spring 2010 CRCT at the 58 schools identified by the Governor's Office of Student Achievement (GOSA) was implemented. In 2011, APS moved to an online nationally normed, computer adaptive assessment system, eliminating the possibility of educator erasures. A 2011-2012 school year support program included a mandatory school day component, afterschool enrichment, a Saturday Academy, and Parent Workshops. A Unit Recovery program was implemented for the 2014-2015 school 
year, allowing students in grades 6-12 who were failing courses to supplement their work on computers to address achievement gaps. The 2014-2015 school year also witnessed mandatory credit recovery periods during the school day at every high school, expansion of credit recovery opportunities in the evening at more schools, and implementation of dropout recovery plans for those students who had left school. Further, the APS was able to increase the number of students participating in Atlanta Virtual Academy.

\section{AUTHOR BIOGRAPHY}

Dr. Jan Colbert is Professor of Accounting at Columbus State University in Columbus, GA. Her research interests include internal control, statistical sampling, COSO, and corporate governance. She has published over 100 articles in journals such as Journal of Accounting Literature, CPA Journal, Internal Auditing, and Journal of Business Case Studies. Dr. Colbert teaches auditing, fraud, statistics, and forensic accounting at both the graduate and undergraduate levels.

\section{REFERENCES}

AASA (2009, February). Atlanta school leader Beverly Hall named National Superintendent of the Year. Retrieved from AASA website: www.aasa.org/content.aspx?id=1592.

Atlanta Journal Constitution (2015, April 2). A timeline of how the Atlanta School cheating scandal unfolded. Retrieved from the AJC website: www.ajc.com/news/news/a-timeline-of-how-the-atlanta-school-cheating-scan/nkkLH/.

Atlanta Public Schools (2015). CRCT erasure analysis and ongoing remediation update. Retrieved from Atlanta Public Schools website: http://atlantapublicschools.us/crctinterventions.

Atlanta Public Schools (2015, May 5). The long-run effects of teacher cheating on student outcomes. Retrieved from Atlanta Public Schools website: http://atlantapublicschools/us/crctreport.

Aviv, Rachel, (2014, July 21). Wrong answer. The New Yorker. Retrieved at The New Yorker website: https://www.google.com/search?q=wrong+answer+rachel+aviv\&oq=wrong+answer+rachel+aviv\&aqs=chrome.69i57. $3535 \mathrm{j} 0 \mathrm{j} 8 \&$ sourceid $=$ chrome\&es_sm $=0$ \&ie $=\mathrm{UTF}-8$.

Blue Ribbon Commission (2010, August 2). 2009 Criterion referenced competency test (CRCT) erasure investigation. Retrieved from Atlanta Public Schools website: http://gov.georgia.gov/00/press/detail/0,2668,78006749_144947052_145624123,00.html.

Burton, Nsenga K (2015, April 20). The real lesson of the Atlanta public schools cheating scandal. The Root. Retrieved from The Root website: http://www.theroot.com/articles/culture/2015/04/the_real_lesson_ of_the_atlanta_public_schools_cheating_scandal.html.

Cassidy, Christina A. (2013, April 2). Atlanta cheating scandal suspects surrender. The Huffington Post. Retrieved from The Huffington Post website: http://www.huffingtonpost.com/2013/04/02/atlanta-cheating-scandalsurrender_n_2998460.html.

Committee of Sponsoring Organizations of the Treadway Commission (2013). Internal Control—Integrated Framework. Retrieved from the COSO website: http://www.coso.org/documents/990025P_Executive_ Summary_final_may20_e.pdf.

Cooper, Eric and Jackson, Phillip (2015, May 19). The Atlanta cheating Scandal: students were the victims, but the school system suffers too. The Huffington Post. Retrieved from The Huffington Post website: http://www.huffingtonpost.com/eric-cooper/the-atlanta-cheating-scan_b_7309084.html.

Deal, Governor Nathan (2011, July 8). Press release. State will complete CRCT probe into Dougherty. Retrieved from Georgia.gov website: https:/gov.georgia.gov/press-releases/2011-07-08/state-will-complete-crct-probe-dougherty.

Deal, Governor Nathan (2011, December 20). Press release. Deal releases Dougherty CRCT investigation report. Retrieved from Georgia.gov website: https://gov.georgia.gov/press-releases/2011-12-20/deal-releases-dougherty-crctinvestigation-report

Dewan, Shaila (2010, August 7). Scandal haunts Atlanta's school chief. The New York Times. Retrieved from The New York Times website: http://www.nytimes.com/2010/08/08/education/08atlanta.html.

Ellis, Ralph and Lopez, Elwyn (2015, April 30). Judge reduces sentences for 3 educators in Atlanta cheating scandal. CNN. Retrieved from Cnn.com: http://www.cnn.com/2015/04/30/us/atlanta-schools-cheating-scandal/.

FBI (2015). Glossary of Terms. Retrieved from FBI website: www.fbi.gov/about-us/investigate/organizedcrime/ glossary.

Foody, Kathleen (2014, September 29). Trial underway in Atlanta schools cheating case). The Huffington Post. Retrieved from The Huffington Post website: http://www.huffingtonpost.com/2014/09/29/atlanta-schools-cheatingtrial_n_5901984.html.

Hall, Beverly L. (2011, May 9). Final quarterly update blue ribbon commission's recommendations of the 2009 criterion referenced competency test (CRCT) erasure investigation. Retrieved from Atlanta Public Schools website: http://cse.google.com/cse?cx=012716672486618045890:d53rghdbv3a\&ie=UTF-8\&q=final +quarterly + update + 
blue+ribbon+commission $\% 27 \mathrm{~s}+$ recommendtions\#gsc.tab=0\&gsc.q=final $\% 20$ quarterly $\% 20$ update $\% 20$ blue $\% 20$ ribbon $\% 20$ commission's $\% 20$ recommendtions\&gsc.page $=1$.

Judd, Alan (2015, April 4). APS cheating case: from first hint of scandal to jury verdict. Atlanta Journal Constitution. Retrieved from Atlanta Journal Constitution website: http://www.myajc.com/news/news/crime-law/aps-cheating-casefrom-first-hint-of-scandal-to-ju/nkk4Z/.

Perdue, Governor Sonny (2009, July 9). Press release. Statement of Governor Sonny Perdue regarding state board of education accepting the recommendations of the governor's office of student achievement. Retrieved from the Georgia.gov website: http://gov.georgia.gov/00/press/detail/ 0,2668,78006749_144947052_145624123,00.html.

Porter, Andrew C. and McMaken, Jennifer (2010, May 11). Identifying Atlanta elementary school that had unusually large gains in student achievement test scores from the year 2007/8 to the year 2008/9. Retrieved from the Atlanta Public School website: http://www.atlantapublicschools.us/cms/lib/GA01000924/Centricity/Domain/39/Porter_Report_1.pdf.

Strauss, Valerie (2015, April 1). How and why convicted Atlanta teachers cheated on standardized tests. The Washington Post. Retrieved from The Washington Post website: http://www.washingtonpost.com/blogs/answersheet/wp/2015/04/01/how-and-why-convicted-atlanta-teachers-cheated-on-standardized-tests/.

Thompson, John (2014, July 30). The New Yorker nails the real lesson of the Atlanta testing scandal. The Huffington Post. Retrieved from The Huffington Post website: http://www.huffingtonpost.com/john-thompson/new-yorker-nails-thereal_b_5624923.html.

United States Public Law 91-452 (1970, October 15). Organized crime control act of 1970 (RICO). Retrieved from the Government Accountability Office website: https://bulk.resource.org/gao.gov/91-452/00004DB3.pdf. 


\section{DISCUSSION QUESTIONS}

1. Who are the key players?

2. How many of Atlanta's elementary and middle schools were found to have educators who had cheated to help students pass Georgia's standardized achievement test?

3. How many former Atlanta educators went to trial?

4. What was the main statute that the former Atlanta educators who went to trial were found guilty of?

5. How many defendants plead guilty to lesser offenses prior to trial?

6. By the time she retired in 2011, Dr. Beverly Hall had received about how much in bonuses from the Atlanta Public Schools?

7. These questions relate to COSO's components and principles.

a. The APS cheating scandal showed that the Atlanta Board of Education had apparently not adequately addressed which of the five components of internal control?

b. The APS cheating scandal showed that the Atlanta Board of Education had apparently not adequately addressed which of the 17 principles of internal control?

8. How did the educators cheat?

9. How did educators arrange to change the test answers?

10. How were educators rewarded in Dr. Hall's administration?

11. How many educators resigned, retired, or lost their appeals?

12. How did the facts of the APS case relate to the three points of the fraud triangle?

13. Why were the APS educators prosecuted under the RICO statute?

14. What are some of the remediation efforts that the APS is undertaking or has undertaken?

15. Has the APS changed its testing procedures for standardized testing from the paper-based system (which allows educator erasures)? 


\section{ANSWERS TO DISCUSSION QUESTIONS}

1 . Who are the key players?

Dr. Beverly Hall, superintendent for 12 years.

- Indicted in 2013. Died 03.02.15 of cancer without going to trial.

Fulton County Grand jury: indicted 35 former employees of APS on racketeering and other charges.

- 21 pleaded guilty to lesser offenses

- 11 were convicted in 2015

- One was acquitted

- Two died before standing trial

APS students: an unknowable number of students were harmed, an entire generation of Atlanta public school students suffered.

Then-Governor Sonny Perdue: ordered a trio of special investigators.

Trio of special investigators: Richard Hyde, Mike Bowers, Bob Wilson.

Georgia Bureau of Investigation (GBI)

2. How many of Atlanta's elementary and middle schools were found to have educators who had cheated to help students pass Georgia's standardized achievement test?

Of Atlanta's elementary and middle schools, 44 were found to have educators who had cheated to help students pass Georgia's standardized achievement test.

3. How many former Atlanta educators went to trial?

Eleven former Atlanta educators went to trial.

4. What was the main statute that the former Atlanta educators who went to trial were found guilty of?

The main statute that the former Atlanta educators were found guilty of was the RICO (Racketeering Influenced and Corrupt Organizations Act) statute.

5. How many defendants plead guilty to lesser offenses prior to trial?

Besides the 11 former Atlanta educators who were found guilty at trial, an additional 21 plead guilty to lesser offenses prior to the trial beginning.

6. By the time she retired in 2011, Dr. Beverly Hall had received about how much in bonuses from the Atlanta Public Schools?

Dr. Beverly Hall received more than $\$ 580,000$ in bonuses by the time she retired.

7. These questions relate to COSO's components and principles.

a. The APS cheating scandal showed that the Atlanta Board of Education had apparently not adequately addressed which of the five components of internal control?

b. The APS cheating scandal showed that the Atlanta Board of Education had apparently not adequately addressed which of the 17 principles of internal control? 
a. Control environment; Risk assessment; Monitoring.

b. The principles most impacted are (using the numbers in the COSO document):

1. Commitment to integrity and ethical values (which supports the control environment component)

7. Determine how risks should be managed (which supports the risk assessment component)

8. Potential for fraud (which supports the risk assessment component)

16. Ongoing and/or separate evaluations (which supports the monitoring component)

17. Communicate internal control deficiencies to parties responsible for taking corrective action (which supports the monitoring component)

8. How did the educators cheat?

The educators held parties to change wrong answer to right answers on students' tests. To accomplish this, the educators erased students' answers and inserted the correct answer. Also, educators falsified reports on test results. Further, shrink wrapped tests were opened, the tests were extracted, and then the tests were resealed.

9. How did educators arrange to change the test answers?

Educators papered over office widows and then met to tamper with test papers during the school day. They erased students' wrong answers and inserted right answers. One school threw an after-hours party while teachers fixed answer sheets while imbibing.

10. How were educators rewarded in Dr. Hall's administration?

At her annual convocation at the Georgia Dome, those whose schools had met test-score targets were permitted to sit near the arena's stage. The remainder had to endure the bleacher seats. Some schools received bonuses based on their standardized test results.

11. How many educators resigned, retired, or lost their appeals?

About 150 educators resigned, retired, or lost their appeals.

12. How did the facts of the APS case fit the three points of the fraud triangle?

Opportunity: The teachers had the opportunity to make erasures (had parties, papered over the windows). The supervisors had the authority to submit falsified reports.

Pressure/Incentive: Pressure on Dr. Hall came from her contract, which provided an incentive to have high test scores. In turn, she pressured the schools to produce high test scores. Seating at the Georgia Dome at the convocation, fear for one's job, and bonuses for an entire school were used to pressure school employees to comply with Dr. Hall's directives.

Rationalization: School employees rationalized the cheating because some were single parents. For all educators, fear for one's job is a powerful rationalization.

13. Why were the APS educators prosecuted under the RICO statute?

RICO pertains to organized crime, which is crime committed through some manner of formalized structure. The objective of organized crime is to obtain money through illegal activities. One of the ways in which members of organized crime groups maintain their positions is through corrupt public officials.

The APS case fits the RICO statute. Dr. Hall received over $\$ 580,000$ in bonuses. Other educators, fearing the loss of their jobs, also participated in the fraud (cheating). Some educators also received bonuses based on their school's test scores. The educators are public officials, as they were employed by a public school system. 
14. What are some of the remediation efforts that the APS is undertaking or has undertaken?

- -12 week accelerated academic recovery program for students who scored below proficient on the Spring, 2010 CRCT

- -Support program in 2011-2012 including a mandatory school day component, afterschool enrichment, a Saturday Academy, and Parent Workshops

- -2014-2015 efforts included mandatory credit recovery periods during the school day at every high school, expansion of evening credit recovery opportunities, dropout recovery plans, and increased attendance in Atlanta Virtual Academy courses.

15. Has the APS changed its testing procedures for standardized testing from the paper-based system (which allows educator erasures)?

Yes, the APS now utilizes an online system for its standardized testing, thus eliminating the opportunity for educator erasures. 